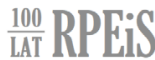

\section{KATEGORIA SŁUSZNOŚCI W POLSKIM ORZECZNICTWIE SĄDOWYM}

\section{WPROWADZENIE}

Przekonanie o roli słuszności w pojmowaniu prawa nie budzi w nauce prawa większych wątpliwości ${ }^{1}$, stanowi ona bowiem istotny czynnik wpływający zarówno na proces tworzenia, jak i stosowania prawa. Zagadnienie słuszności w praktyce orzeczniczej nabiera znaczenia również w kontekście możliwych konfliktów aksjologicznych, które w literaturze teoretycznoprawnej określane są mianem tzw. trudnych przypadków (hard cases). Nie wchodząc w szczegółową analizę różnych koncepcji trudnych przypadków ${ }^{2}$, można w ramach pewnego uproszczenia zaryzykować konkluzję, że dotyczą one sytuacji, w których przez zastosowanie określonego przepisu sędzia zmuszony jest do wydania rozstrzygnięcia, z którym on sam się nie zgadza ze względu na wyznawane standardy słuszności ${ }^{3}$. Na doniosłość podjętego tematu wskazuje znacząca liczba polskich orzeczeń ${ }^{4}$, w których sądy odwołują się do słuszności, wskazując na m.in. uwzględnienie w toku rozumowania względów słuszności czy rażące naruszenie zasad słuszności. Celem niniejszego artykułu jest przedstawienie wyników analizy polskiego orzecznictwa w zakresie powoływania się przez sędziów na słuszność.

W ramach wprowadzenia, wobec przyjętego przedmiotu artykułu, zasadne wydaje się podjęcie jeszcze jednej, istotnej dla dalszych rozważań kwestii, a mianowicie relacji pomiędzy prawem a słusznością. W zależności od przyjętych założeń doktrynalnych w zakresie istoty prawa słuszność może być powiązana z pra-

\footnotetext{
" Sara Smyczek-Gołębiewska, Uniwersytet Śląski w Katowicach, sara.smyczek@us.edu.pl,https://orcid.org/0000-0003-3210-2813

${ }^{1}$ Leszczyński (2011): 45, Wróblewski (1963): 203-232.

${ }^{2}$ Zajadło (2008): $18 \mathrm{n}$.

${ }^{3}$ Zajadło (2017): 35.

${ }^{4}$ Przykładowo, w bazie Lex Omega fraza „względy słuszności” pojawia się w 6035 orzeczeniach (stan na 14 lutego 2021 r.).
} 
wem w sposób alternatywny - może stanowić jego ekskluzywny albo inkluzywny element definicyjny ${ }^{5}$. Ponadto różny może być wymiar uwzględnienia tego kryterium w rozumieniu istoty prawa. Wyrazem relacji ekskluzywności, która łączy się z koncepcją klasycznego pozytywizmu prawniczego, jest wiązanie przez XIX-wiecznego twórcę doktryny pozytywistycznej, Johna Austina, istoty prawa z rozkazem suwerena oraz obowiązkiem jego wykonania. Nie jest to wprawdzie jednoznaczne $\mathrm{z}$ odmówieniem kryteriom moralnym jakiejkolwiek roli w funkcjonowaniu systemu prawnego, ale słuszność jest traktowana jako odrębny ontologicznie element, który niejako „Z zewnątrz” wchodzi do obrotu prawnego. Relacja inkluzywności natomiast, związana z koncepcjami prawnonaturalnymi, uwzględnia kryterium słuszności w tworzeniu definicji prawa w taki sposób, że prawem uznaje się wyłącznie taką regulację normatywna, która spełnia test słuszności. Skoro zatem istota prawa opiera się na idei słuszności, mniej istotne wydaje się to, w jaki sposób to kryterium „wewnętrzne” przejawia się w poszczególnych działaniach tworzenia i stosowania prawa. We współczesnych koncepcjach teoretycznoprawnych ${ }^{6}$ można jednak zauważyć zatarcie wspomnianych ostrych podziałów doktrynalnych przez częściowe włączanie słuszności do istoty prawa, nawet przy zasadniczym pozostawaniu na stanowisku pozytywizmu, tym razem już nazywanego wyrafinowanym czy miękkim. W konsekwencji nie sposób dziś wskazać na rozbudowaną koncepcję prawa, która nie uwzględniałaby choć $\mathrm{w}$ niewielkim zakresie kryterium słuszności jako emanacji roli wartości moralnych w prawie. Współcześnie refleksja nad relacjami prawa i słuszności nie stawia już alternatywnie kwestii, czy słuszność stanowi immamentną cechę ustaw, czy jest pozaustawowym narzędziem ich korektury, poszukując zamiast tego tzw. trzeciej drogi ${ }^{7}$. Znajduje ona swój wyraz w zorientowaniu na praktykę prawa i dążeniu do realizacji stuszności in concreto. Mając powyższe na uwadze, jednoznaczna odpowiedź na pytanie o relacje prawa i słuszności nie wydaje się niezbędnym założeniem teoretycznym do poczynienia rozważań w obrębie praktyki orzeczniczej, które, co więcej, mogą okazać się pomocne w jej sformułowaniu.

\section{SŁUSZNOŚĆ W STOSOWANIU PRAWA}

Na wstępie należy podkreślić, że odwołania do słuszności pojawiają się w orzeczeniach polskich sądów stosunkowo licznie ${ }^{8}$. W części orzeczeń słuszność stanowi argument, na który powołują się strony postępowania. Przypadki te jednak nie zostaną objęte zakresem analizy w niniejszym opracowaniu, ze względu na niski stopień doniosłości dla osiagnięcia celu prowadzonego wywodu. Poniżej zostaną zatem przedstawione fragmenty jedynie takich orzeczeń, w których na słuszność powołuje się sąd.

\footnotetext{
5 Leszczyński (2011): 45.

${ }_{6}$ Zirk-Sadowski (2000): $197 \mathrm{n}$.

7 Sobański (2001): 10.

8 Por. przyp. 4.
} 
Na wstępie należy wyróżnić trzy przypadki, w których może znaleźć się organ powołujący się na słuszność na etapie stosowania prawa. Pierwsza sytuacja zajdzie, gdy norma prawna stanowiąca podstawę wydania orzeczenia bezpośrednio wskazuje na słuszność jako kryterium, które organ powinien uwzględnić przy wydawaniu decyzji. Za przejaw słuszności na płaszczyźnie tworzenia prawa można uznać klauzule generalne. W doktrynie występują różnorodne koncepcje dotyczące charakteru tego pojęcia. Nie wchodząc w szczegółowe rozważania, można zauważyć w piśmiennictwie dwa przeciwstawiane sobie stanowiska charakteryzujące klauzulę generalną: 1) jako zwrot odsyłający do ogólnie ukierunkowanych, ocennych kryteriów pozaprawnych ${ }^{9}$ lub 2) jako zwrot, którego konkretna treść jest ustalana w procesie stosowania prawa ${ }^{10}$. Z uwagi na rozbieżności występujące pomiędzy tymi dwoma stanowiskami niemożliwe wydaje się ich połączenie ${ }^{11}$. Wprowadzając do przepisów klauzule wskazujące na słuszność, prawodawca uznaje tym samym jej wartość. Klauzule te najczęściej przyjmują postać względów słuszności ${ }^{12}$ lub zasad słuszności ${ }^{13}$, rzadziej słuszności samej w sobie ${ }^{14}$. Zależnie od tego, czy słuszność jest wskazana jako wyłączne kryterium, czy też współwystępuje razem z innymi ${ }^{15}$, różny będzie zakres jej wpływu na ostateczną treść decyzji. Tego rodzaju klauzule mogą uzależniać od względów słuszności ocenę zasadności żądania w konkretnym przypadku, np. naprawienia szkody wyrządzonej przez zgodne z prawem wykonywanie władzy publicznej (art. $417^{2}$ k.c.) lub świadczenia wyrównawczego przez agenta po rozwiązaniu umowy agencyjnej (art. $764^{3} \S 1$ k.c.). Na osobną uwagę zasługuja przepisy, w których klauzula wskazująca na słuszność jest elementem tworzącym wyjątki od reguły np. w art. $117^{1}$ k.c., który uprawnia sąd do nieuwzględniana upływu terminu przedawnienia roszczenia przysługującego przeciwko konsumentowi, jeżeli wymagają tego względy słuszności.

Drugi przypadek określa sytuację, gdy prawodawca do przepisu, który stanowi podstawę podjęcia decyzji, nie wprowadza klauzuli wskazującej na słuszność, lecz inne wartości (np. dobre obyczaje, zasady współżycia społecznego) lub zwroty niedookreślone (np. w wypadkach szczególnie uzasadnionych).

9 Por. Leszczyński (2016): 14; (2000): 3; Ziembiński (1980): 242. Stanowisko zostało poddane krytyce. Zob. Nowacki (1988): 84; Pawełczyk (1984): 90. Por. także Ziembiński (1989): 16.

10 Nowacki (1988): 101; Pawełczyk (1982): 96-97.

11 Zgodnie z pierwszym stanowiskiem klauzule generalne odsyłają do pewnych ocen (zewnętrznych wobec sędziego), natomiast drugie stanowisko wskazuje, że klauzule generalne sa zależne od ocen organu stosującego prawo, formułowanych w konkretnym rozpatrywanym przypadku. Zob. Tkacz (2003): 18-24.

12 Np. art. $117^{1}$ k.c., art. $417^{2}$ k.c., art. $761^{2}$ k.c., art. $764^{3} \S 1$ k.c., art. $764^{4}$ ust. 1 k.c., art. 827 $\S 1$ k.c., art. $61^{4} \S 1$ k.r.o.

13 Np. 556 ust. 2 rozporządzenie Ministra Zdrowia z 31 marca 2003 r. w sprawie postępowania w sprawach odpowiedzialności zawodowej farmaceutów (Dz. U. 2003, Nr 65, poz. 612), §57 ust. 2 rozporządzenie Ministra Zdrowia z 24 września 2004 r. w sprawie szczegółowych zasad i trybu postępowania dyscyplinarnego w stosunku do diagnostów laboratoryjnych (Dz. U. 2004, 226 2295),

${ }^{14}$ Np. „słuszny interes pracownika lub ubezpieczonego” art. 469 k.p.c, „słuszne wynagrodzenie”, art. 217 ustawy z 18 września 2001 r. - Kodeks morski (t.jedn.: Dz. U. 2018, poz. 2175).

15 Np. art. $491^{10}$ ust. 2 a ustawy z 28 lutego 2003 r. - Prawo upadłościowe (t.jedn.: Dz. U. 2020, poz. 1228). 
Organ stosujący prawo, ze względu na wystapienie powyższych konstrukcji prawnych, na etapie interpretacji przepisu powołuje się na słuszność, mimo iż nie została ona bezpośrednio wymieniona w podstawie prawnej. Organ, korzystając ze swojej swobody decyzyjnej w ramach czynności interpretacyjnych, wywodzi z danego przepisu kryterium słuszności, na które następnie powołuje się w decyzji stosowania prawa. Ciekawy przykład stanowi art. 102 k.p.c., wskazujący, że „w wypadkach szczególnie uzasadnionych sąd może zasądzić od strony przegrywającej tylko część kosztów albo nie obciążać jej w ogóle kosztami”. Przepis ten jest w orzecznictwie polskim jednolicie interpretowany jako wprowadzający zasadę słuszności ${ }^{16}$. Jako drugi przykład posłużyć może art. 5 k.c. ${ }^{17}$, który - mimo że nie odwołuje się wprost do słuszności - zawartą w nim zasadę współżycia społecznego utożsamia się w orzecznictwie ze słusznością ${ }^{18}$. Przyczyną może być zastapienie przez klauzulę zasad współżycia społecznego, w Kodeksie cywilnym i w innych ustawach z zakresu prawa cywilnego, dawnych klauzul słuszności oraz dobrej wiary w znaczeniu obiektywnym ${ }^{19}$. Zdaniem Jerzego Wróblewskiego, klauzula „zasad współżycia społecznego” jest funkcjonalnym równoważnikiem słuszności ${ }^{20}$.

Leszek Leszczyński wskazuje, że z uwagi na różnorodną treść klauzul generalnych w przepisach prawa można wyróżnić kryteria słusznościowe wskazywane przez prawodawcę z nazwy (względy czy zasady słuszności), kryteria słusznościowe korzystające z innych nazw, ale wskazujące na kryteria moralne (zasady współżycia społecznego, dobre obyczaje), oraz kryteria słusznościowe, które nawiązują nazwą do wartości moralnych, ale zawieraja potencjalnie także inne wartości (zasady sprawiedliwości społecznej, interes społeczny, interes publiczny) ${ }^{21}$.

Dwa wyżej przedstawione przypadki polegają na włączeniu słuszności do podstaw orzekania zgodnie z wolą prawodawcy pozytywnego, który wskazuje na to kryterium przez klauzule generalne lub inne konstrukcje otwierające zakres poszukiwań normatywnych podstaw decyzji ${ }^{22}$. Ten rodzaj odwołania do słuszności zachodzi w ramach sformalizowanych procesów stosowania prawa nie tylko sądowego, ale również administracyjnego (przy decyzjach opartych na uznaniu administracyjnym ${ }^{23}$. Przejawia się jednak przede wszystkim w formie odesłań w przepisach szczegółowych, dotyczących konkretnej instytucji prawnej, ponieważ wprowadzanie podstaw odwoływania się do kategorii słuszności w przepisach ogólnych aktów podstawowych dla danej gałęzi prawa

16 Wyroki SA: w Gdańsku z 7 czerwca 2018 r., I ACa 808/17; w Szczecinie z 8 lutego 2017 r., I ACa 766/16; postanowienie SN z 22 czerwca 2012 r., V CZ 17/12.

17 Ustawa z 23 kwietnia 1964 r. - Kodeks cywilny (t.jedn: Dz. U. 2020, poz. 1740).

18 Wyroki SN: z 20 grudnia 2017 r., I CSK 163/17; z 26 lipca 2011 r., I PK 22/11.

19 Nazaruk (2019): Komentarz do art. 5.

20 Wróblewski (1970): 114.

21 Leszczyński (2011): 47.

22 Leszczyński (2011: 47) pisze o punktowym wpływie słuszności na prawo.

${ }^{23} \mathrm{Z}$ uwagi na istotność problematyki dyskrecjonalności administracyjnej i roli słuszności w orzeczeniach administracyjnych oraz ograniczone rozmiary niniejszego artykułu, przedstawienie ww. materii w sposób pogłębiony zasługuje na odrębne opracowanie. Zob. Szot (2011): 175-182; Janiszewski (2020): 101-113; Rożek (2016): 25-34. 
czy całego systemu prawnego mogłoby przybliżyć tę formę stosowania kategorii słuszności do pewnych aspektów orzecznictwa słusznościowego ${ }^{24}$.

Trzeci przypadek odwołania się do słuszności przez organ stosujący prawo polega na samodzielnym przywołaniu tego kryterium. Językowa warstwa przepisu nie wskazuje na słuszność ani żadne inne wartości, które organ powinien wziąć pod uwagę lub którymi ma się kierować, wydając decyzję. To od niego zależy, czy słuszność w ogóle zostanie uwzględniona na etapie rozstrzygania, a jeśli tak, to jaka będzie jej funkcja. Organ przywołuje słuszność w ramach przysługującej mu swobody decyzyjnej. Należy wskazać, że ten rodzaj odwołania do słuszności w orzecznictwie wydaje się znacznie ciekawszy z punktu widzenia prowadzonych badań, gdyż nie jest on zdeterminowany odgórną decyzją ustawodawcy (tj. treścią przepisu), ale stanowi wyraz autonomii sędziego i może być źródłem wiedzy o aksjologicznych podstawach podjętej przez niego decyzji. Słuszność w tym przypadku najczęściej przyjmuje dwie formy: 1) argumentu - gdy powołanie się na nią ma za zadanie wzmocnić lub obalić pewne sformułowane wcześniej twierdzenia, lub 2) kryterium oceny - gdy w ramach dyskrecjonalnej władzy organ, opierając się na słuszności, formułuje swoją opinię na temat stanu faktycznego lub czynności podejmowanych w sprawie.

\section{ANALIZA ORZECZNICTWA}

Z uwagi na wskazane uprzednio istotne znaczenie trzeciego rodzaju odwołania się do słuszności, uzasadnione wydaje się przedstawienie przykładów z orzecznictwa. W pierwszej kolejności omówione zostaną sytuacje, w których słuszność, samodzielnie przywołana przez sędziego, pełni w ramach prowadzonego wywodu funkcję argumentu. Najczęściej dzieje się tak w ramach dokonywanej interpretacji przepisów, odwołanie do słuszności może bowiem zarówno potwierdzać rezultaty przeprowadzonej wykładni, jak i się im sprzeciwiać. Sądy wykorzystują argument ze słuszności także w uzasadnieniu czasstkowych decyzji kluczowych do podjęcia ostatecznego rozstrzygnięcia, a nawet przy mniej wiążących ustaleniach (jak np. postulatach za zmianą prawa).

Jednym z przykładów ${ }^{25}$ wykorzystania argumentu ze słuszności w celu wzmocnienia wyników dokonanej przez sąd wykładni prawa może być posta-

${ }^{24}$ Leszczyński (2011: 46) orzecznictwem słusznościowym nazywa orzecznictwo oparte wyłącznie na kryterium słuszności, bez udziału sformalizowanych kryteriów prawnych. Stanowi rodzaj alternatywnego, a po części także konkurencyjnego sposobu podejmowania decyzji w stosunku do sformalizowanego obrotu. Współcześnie występuje zarówno w postaci nawiązywania do equity law, jak i w postaci różnych form alternatywnego rozwiązywania sporów.

${ }_{25}$ Por. uchwała SN z 30 listopada 2016 r., III CZP 74/16: „Za wykładnia, że umożliwienie poszkodowanemu w wypadku komunikacyjnym korzystania z samochodu zastępczego powoduje spełnienie przesłanek powstania roszczenia regresowego przewidzianego w art. 828 § 1 k.c., przemawiają także wnioski płynące z wykładni celowościowej oraz względy słuszności”; wyrok SN z 23 października 2019 r., I CSK 421/18: „Taka interpretacja przepisów przejściowych ma ten walor, że pozwoli na jednakowe potraktowanie podmiotów, których zbieżne rodzajowo roszczenia 
nowienie Sądu Najwyższego ${ }^{26}$, w którym rozważano, w jaki sposób zinterpretować i zastosować w konkretnej sprawie określenie „uzasadnione wydatki stron”27. Sąd uznał, że „co prawda wskazany przepis nie określa, jakie wydatki [...] należy uznawać za uzasadnione, ale jest oczywiste, że chodzi w nim o wydatki niezbędne dla realizowania funkcji procesowych strony. Względy słuszności [wyróżnienie - S.S.-G.] przemawiaja za tym, aby w skład uzasadnionych wydatków nie wchodziły kwoty wykładane przez stronę w sposób ewidentnie nieroztropny, wywołany rażącym niedbalstwem". Sąd Najwyższy, powołując się w ramach interpretacji przepisu na względy słuszności, doprecyzował nieostre wyrażenie i dostosował je do okoliczności faktycznych danej sprawy ${ }^{28}$. Jako kolejny przykład można przytoczyć postanowienie Sądu Apelacyjnego w Łodzi ${ }^{29}$, w którym stwierdzono, że: „Należy podkreślić, że za tego rodzaju wykładnią przepisów rozporządzenia Ministra Sprawiedliwości z dnia 10 września 1991 r. w sprawie określenia wysokości wpisów w sprawach cywilnych (Dz. U. Nr 85 poz. 390) przemawiają nie tylko względy formalno-prawne, ale przede wszystkim względy słuszności[wyróżnienie - S.S. -G.]”. Inne orzeczenie ${ }^{30}$, w którym Sąd Najwyższy posłużył się odwołaniem do słuszności, aby potwierdzić przyjęty sposób interpretacji i wytłumaczyć także ratio legis przepisu, dotyczyło prawa zatrzymania z 461 k.c. ${ }^{31}$ „Posiadaczowi przysługuje prawo wystapienia z roszczeniem o zwrot nakładów po wystapieniu właściciela z roszczeniem windykacyjnym. Tylko przy takim założeniu, zdaniem Sądu Najwyższego, instytucja prawa zatrzymania zachowuje swoja praktyczną wartość. Spełniona jest wówczas również racja prawna przepisu art. $461 \S 1$ k.c., bowiem względy słuszności wymagają [wyróżnienie - S.S.-G.], aby żadna ze stron nie została zmuszona do wykonania swojego zobowiązania bez jednoczesnego otrzymania lub co najmniej zabezpieczenia spełnienia świadczenia, które jej się należy od drugiej strony [...]”. Podobnie sąd, odwołując się do względów słuszności, wyjaśnia motyw ustawodawczy art. $359 \S 2^{1}$ k.c. $^{32}$ : „Powołana regulacja prawna przesądza, że odsetki wynikające z czynności prawnej nie mogą w skali roku przekraczać dwukrotności

powinny - ze względów słuszności - zostać potraktowane jednolicie"; postanowienie SN z 24 lutego 2017 r., IV CSK 224/16.

${ }^{26}$ Postanowienie SN z 3 lutego 2004 r., V KK 370/03.

${ }^{27}$ Art. $616 \S 1$ pkt 2 ustawy z 6 czerwca 1997 r. - Kodeks postępowania karnego (Dz. U. 2020, poz. 30): „Do kosztów procesu należą: [...] 2) uzasadnione wydatki stron, w tym z tytułu ustanowienia w sprawie jednego obrońcy lub pełnomocnika”.

${ }^{28}$ Por. wyrok SA w Łodzi z 29 grudnia 2017 r., I ACa 545/17: „Powyższa trudność w szacowaniu kwoty szkody stała się powodem, dla którego sąd ma przyznać "stosowne odszkodowanie», a więc odpowiednie w danej sytuacji, w świetle zdrowego rozsądku i względów słuszności”.

${ }^{29}$ Postanowienie SA w Łodzi z 19 marca 1992 r., I ACz 84/92.

${ }^{30}$ Wyrok SN z 7 maja 2009 r., IV CSK 27/09.

${ }^{31}$ Art. 461. § 1. ustawy z 23 kwietnia 1964 r. - Kodeks cywilny (Dz. U. 2020, poz. 1740): „Zobowiązany do wydania cudzej rzeczy może ją zatrzymać aż do chwili zaspokojenia lub zabezpieczenia przysługujących mu roszczeń o zwrot nakładów na rzecz oraz roszczeń o naprawienie szkody przez rzecz wyrządzonej”.

${ }_{32}$ Art. 359 § 21 ustawy z 23 kwietnia 1964 r. - Kodeks cywilny (Dz. U. 2020, poz. 1740): „Maksymalna wysokość odsetek wynikających z czynności prawnej nie może w stosunku rocznym przekraczać dwukrotności wysokości odsetek ustawowych". 
wysokości odsetek ustawowych. Motywem tego przepisu są w zględy słuszności [wyróżnienie - S.S.-G.], a mianowicie potrzeba ochrony dłużnika przed lichwą" ${ }^{33}$, a w innym przypadku ${ }^{34}$ - artykułu 93 k.c. ${ }^{35}$ : „Należy wskazać, że zgodnie z art. $93 \S 1$ k.c. jeżeli strona, której zależy na nieziszczeniu się warunku, przeszkodzi w sposób sprzeczny z zasadami współżycia społecznego ziszczeniu się warunku, następują skutki takie, jakby warunek się ziścił. [...] Rozwiąanie to - kwalifikowane w doktrynie jako swoista kara cywilna - jest uzasadnione względami słuszności [wyróżnienie - S.S.-G.] i oparte na założeniu, że nikt nie powinien uzyskiwać korzyści za pomoca działań nielojalnych (nagannych) i społecznie nieakceptowanych”.

W ramach prowadzonej przez sąd interpretacji można wskazać również sytuacje, w których odwołanie do słuszności służy zakwestionowaniu wyników wykładni językowej, np. sąd, interpretując pojęcie czynności, które prowadzą do przerwania biegu przedawnienia, wskazał: „Wykładnia literalna tego przepisu może prowadzić do zaskakującego wniosku, że jedynie wytoczenie powództwa o zobowiązanie do złożenia oświadczenia woli w sprawie przeniesienia własności nieruchomości prowadziłoby do przerwania biegu przedawnienia roszczenia. Taki rezultat wykładni w niniejszej sprawie naruszałby jednak poczucie słuszności”"36. W innej sprawie ${ }^{37} \mathrm{SN}$, wobec konieczności interpretacji przepisów o dziedziczeniu gospodarstw rolnych, w tym definicji osoby stale niezdolnej do pracy, uznał potencjalnego spadkobiercę, który od dziecka był niewidomy, a mimo to utrzymywał się z pracy jako muzyk, za trwale niezdolnego do pracy: „przeciwna bowiem wykładnia, w wyniku której osoba dotknięta tak poważnym kalectwem nie dziedziczyłaby gospodarstwa rolnego tylko dlatego, że pracowała, w sposób oczywisty naruszałaby poczucie słuszności”.

Niejednokrotnie odwołanie do słuszności stanowi także argument przemawiający za lub przeciw podjęciu określonego rozstrzygnięcia w zakresie skutków prawnych ${ }^{38}, \mathrm{np}$. ustalania wysokości należnego odszkodowania lub zadośćuczynienia ${ }^{39}$. W jednym z orzeczeń ${ }^{40}$ sąd wskazał, że „przyznanie po-

${ }^{33}$ Wyrok SO w Łomży z 24 stycznia 2020 r., I Ca 20/20.

${ }^{34}$ Wyrok SA w Warszawie z 3 czerwca 2016 r., I ACa 902/15.

${ }_{35}$ Art. 93 ustawy z 23 kwietnia 1964 r. - Kodeks cywilny (Dz. U. 2020, poz. 1740): „§ 1. Jeżeli strona, której zależy na nieziszczeniu się warunku, przeszkodzi w sposób sprzeczny z zasadami współżycia społecznego ziszczeniu się warunku, następują skutki takie, jakby warunek się ziścił. § 2. Jeżeli strona, której zależy na ziszczeniu się warunku, doprowadzi w sposób sprzeczny z zasadami współżycia społecznego do ziszczenia się warunku, następują skutki takie, jakby warunek się nie ziścił”.

${ }^{36}$ Wyrok SN z 20 maja 2011 r., IV CSK 91/11.

${ }^{37}$ Postanowienie SN z 3 czerwca 2011 r., III CSK 331/10.

${ }^{38}$ Zob. wyrok SA w Szczecinie z 21 maja 2013 r., I ACa 101/13: „W tym stanie rzeczy Sąd doszedł do przekonania, że względy słuszności przemawiają za tym, aby powód został pozbawiony możliwości dochodzenia roszczenia o zachowek po swej matce R. M., Sąd miał przy tym na uwadze to córka pozwanego sprawowała bezpośrednią stała opiekę nad spadkodawczynią". Por. wyrok SN z 5 lipca 2007 r., II CSK 140/07; wyrok SA w Białymstoku z 13 kwietnia 2016 r., I ACa 667/14.

${ }^{39}$ Por. wyrok SN z 18 lipca 2014 r.; IV CSK 631/13; wyrok SA w Szczecinie z 10 listopada 2016 r., I ACa 696/16; wyrok SO we Wrocławiu z 12 kwietnia 2010 r. III KO 38/09.

${ }^{40}$ Postanowienie SN z 13 maja 2005 r., II PK 414/04. 
wodowi - kosztem majątku pozwanej Spółki, pochodzącego w całości z mienia gminnego - prawa do odszkodowania w wysokości wynagrodzenia za pracę za 3 lata i 9 miesięcy - rażąco naruszałoby zasady słuszności rozumiane jako normy moralne ograniczające uprawnienia określone przepisami prawa lub umową" W innym przypadku ${ }^{41}$ argument ze słuszności służył jako potwierdzenie zasadności wysokości zadośćuczynienia: „W związku z tym zasady słuszności nakazywały, aby pozwany zadośćuczynił krzywdzie, jakiej doznał powód. Według Sądu kwota 70.000 zł zadośćuczynienia będzie odpowiednia [...]. Zapłata przez pozwanego tak określonej kwoty pozostaje również w zgodzie z zasadami słuszności”. Na szczególną uwagę zasługuje orzeczenie ${ }^{42}$, w którym sąd okręgowy, wskazując przyczyny oddalenia powództwa, w bardzo bezpośredni sposób uwypuklił znaczenie względów słuszności w podjęciu rozstrzygnięcia: „Opisana wyżej sytuacja osobista i majątkowa pozwanej uzasadniałaby oddalenie powództwa ze względu na zasady słuszności, nawet gdyby istniała podstawa prawna do zasądzenia jakiejkolwiek należności na rzecz powoda”.

W praktyce orzeczniczej można wyróżnić także przypadki ${ }^{43}$ powołania się na słuszność jako argument za wprowadzeniem określonych zmian w prawie, jednak z uwagi na niewielką doniosłość merytoryczną tych wzmianek nie będa one przedmiotem niniejszego artykułu.

Odwołania do słuszności poczynione przez sąd w ramach swobody decyzyjnej (tj. nie na podstawie klauzuli generalnej) rzadziej przyjmuja postać kryterium oceny. Może ona dotyczyć pewnej powtarzajacej się w obrocie prawnym praktyki ${ }^{44}$, przybierającej wtedy postać nie tyle jednostkowej opinii dotyczacej konkretnej sytuacji faktycznej ${ }^{45}$, ile stanowiska w sprawie istotnego zjawiska

41 Wyrok SA w Szczecinie z 13 marca 2013 r., I ACa 836/12.

42 Wyrok SO w Płocku z 14 sierpnia 2019 r., IV Ca 411/19.

43 „Poza rozważaniami w toku niniejszego postępowania pozostaje oczywiście kwestia, czy redakcja art. 84 ust. 5 prawa o ruchu drogowym nie powinna być w przyszłości zmieniona w taki sposób, aby obejmowała ona zarówno zatrzymanie, jak i zwrot prawa jazdy, za czym mogłyby przemawiać względy słuszności [...]”, uchwała z 14 września 1990 r. SN V KZP 21/90.

44 Zob. wyrok SR w Gdyni z 12 marca 2019 r., I C 1301/14: „Należy jednak mieć na szczególny kontekst sytuacyjny związany z ww. umowa. W obrocie powszechnym nie można uznać za sprzeczne ze względami słuszności prowadzenia negocjacji z jednoczesnym darowaniem kontrahentowi oznaczonych korzyści w celu skłonienia go do zawarcia umowy”; „Sąd przy ocenie stanu faktycznego i stosowaniu prawa do powszechnie przyjmowanych norm moralnych. [...] prawa cywilnego oparty jest bowiem na założeniu, że nie zasługują na ochronę prawną czynności prawne wprawdzie zgodne pod względem formalnym z prawem, lecz godzące w ogólnie akceptowane względy słuszności obowiązujące w społeczeństwie”. Por. wyrok SO w Katowicach z 15 grudnia 2016 r., II C 215/15: „Reasumując, kara umowna musi być uznana za wygórowaną rażąco, gdy dysproporcja między wysokością kary umownej, a możliwym interesem wierzyciela jest szokująca i narusza poczucie słuszności”; wyrok SA w Warszawie z 21 grudnia 2016 r., VI ACa 1558/15.

45 Należy wskazać przykłady orzeczeń, w których sąd wyraża swoją ocenę dotyczącą sytuacji faktycznej, powołując się na względy/zasady słuszności, np. wyrok SA w Szczecinie z 25 kwietnia 2018 r., I ACa 959/17: „W niniejszej sprawie sąd wziął pod uwagę, że zdarzenie z 5 marca 2010 r. spowodowało istotne i nieodwracalne skutki dla stanu zdrowia powoda, który doznał ciężkiego kalectwa, a w konsekwencji utracił także zdolność do wykonywania pracy zarobkowej. Okoliczności te w ocenie Sądu nie mogą stanowić jednak wystarczającej podstawy do nałożenia na pozwanego obowiązku naprawienia szkody wyrządzonej powodowi. Przeciwko temu przemawiają właśnie względy słuszności związane z ocenę zachowania samego powoda podczas zdarzenia z 5 marca 
w rzeczywistości społeczno-prawnej. Przykładem negatywnej oceny może być następujące orzeczenie ${ }^{46}$ : „W orzecznictwie Sądu Najwyższego, które należy podzielić wyrażano przy tym pogląd, iż również w niepracowniczych stosunkach zobowiązaniowych nawiązywanych między przedsiębiorcami brak jakiegokolwiek ekwiwalentu za wprowadzenie umownego zakazu konkurencji po ustaniu umowy sankcjonowanego karą umowną może być oceniony jako sprzeczny z zasadami słuszności”. Podobnie sąd okręowy ${ }^{47}$, wydając wyrok, wskazał, że „nie może pozostawać w zgodzie z zasadami słuszności żądanie obciążenia nieruchomości cudzej w sytuacji, gdy cel ustanowienia służebności można osiagnąć we własnym zakresie bez naruszania własności innych podmiotów”. Sformułowanie przez sąd tego rodzaju oceny każdorazowo związane jest z wartościowaniem i wyborem aprobowanego rozumienia zasad czy względów słuszności.

W praktyce orzeczniczej można wyróżnić także występowanie terminów „słuszność”, „słuszny” przyjmujących znaczenie odbiegające od rozumienia wcześniej zarysowanego. W języku polskim ${ }^{48}$ wyraz „słuszność” utożsamiany również bywa z pojęciem prawidłowości, trafności, np. w zdaniu: „Sąd przyznał słuszność powodowi uznając, że zostały spełnione przesłanki z art. 405 k.c. przez bezpodstawne wzbogacenie pozwanej Gminy kosztem powoda" ${ }^{49}$. Słuszność stanowi w tym przypadku kryterium wartościowania, lecz zasadniczego odległego od wartościowań etycznych. Chodzi tutaj bowiem o ocenę logicznej wartości, logicznego uzasadnienia sądów na temat pewnych faktów ${ }^{50}$. Słuszność w tym rozumieniu jednak wykracza poza zakres badawczy pracy, dlatego nie będzie ona przedmiotem dalszych rozważań.

\section{WNIOSKI}

Celem podsumowania dokonanych ustaleń sformułowane zostaną pewne wnioski natury ogólnej, dotyczące odwołań do słuszności w orzeczeniach polskich sądów.

2010 r. Sąd podkreślił, że to sam powód swoim niezgodnym z prawem zachowaniem doprowadził do konieczności interwencji policji i następnie użycia broni palnej”. Por. wyrok SN z 9 stycznia 2019 r., I CSK 708/17.

46 Wyrok SA w Gdańsku z 14 maja 2013 r., I ACa 174/13.

47 Postanowienie SO w Nowym Sącz z 14 października 2014 r., III Ca 473/14.

48 Słownik języka polskiego pod red. M. Szymczaka przymiotnik słuszny definiuje w sposób następujący: słuszny: „-1. 'zawierający rację, trafny’: Słuszne wnioski, uwagi, propozycje. Słuszne rozumowanie. Słuszna ocena, opinia. Słuszny pogląd. Uznać coś za słuszne. 2. "usprawiedliwiony, uzasadniony’: Słuszny wybór. Słuszny wyrok. Słuszne pretensje, zarzuty, żądania. Słuszny żal”. Analogicznie rzeczownik słuszność to: racja, prawda, właściwość, trafność, sensowność.

49 Wyrok SN z 9 stycznia 2019 r., I CSK 722/17.

50 Teorię słuszności opartą na ocenie formalno-logicznej sformułował Eugeniusz Bautro (1925: 130), obok pojęcia poczucia prawnego wyróżnił także poczucie słuszności, które jest ocena o logicznym uzasadnieniu, gdyż stanowi opinię o jakichś faktach, wyrażając przy tym wartość logiczna. 
Po pierwsze, słuszność w różnym stopniu może wywierać wpływ na treść rozstrzygnięć podejmowanych $\mathrm{w}$ ramach stosowania prawa. W niektórych sytuacjach sąd na podstawie znajdujących zastosowanie w danej sprawie przepisów prawa (występujących w nich klauzulach generalnych) powinien rozważyć uwzględnienie słuszności, w innych natomiast dobór tego kryterium oraz jego rola będą zależały wyłącznie od arbitralnej decyzji podmiotu decyzyjnego. Warto również wskazać, iż z powodu nierozerwalnych związków wiążących słuszność z innymi wartościami organ orzekający może korzystać z tego kryterium w sposób zupełnie nieświadomy. Możliwe są również sytuacje, gdy w pisemnym uzasadnieniu decyzji sąd celowo będzie pomijać słuszność jako kryterium, którym się faktycznie kierował, lub wprost przeciwnie - będzie się nim posługiwać jedynie jako swego rodzaju „ozdobnikiem”, niebędącym odzwierciedleniem rzeczywistych podstaw aksjologicznych podjętego rozstrzygnięcia.

Po drugie, na podstawie przeprowadzonej analizy orzecznictwa należy stwierdzić, że w przeważającej części orzeczeń sądy odwołują się do słuszności z pominięciem wyjaśnienia tego pojęcia czy uzasadnienia jego zastosowania. W związku z tym można pokusić się o konkluzję, że niemożliwe jest uniknięcie choć niewielkiej dozy subiektywizmu przy przywołaniu słuszności, w szczególności gdy sąd czyni tak z własnej inicjatywy. Należy wskazać również, że bierność w zakresie definiowania słuszności w praktyce orzeczniczej i związane z tym jej intuicyjne pojmowanie prawdopodobnie wynikają z braku określenia sposobu rozumienia tego pojęcia na samym początku jego funkcjonowania w polskim systemie prawnym. Doktryna prawa II RP nie wyjaśniła go, uznając za termin zrozumiały intuicyjnie, który w niewątpliwy sposób odsyła do wartości moralnych ${ }^{51}$. Na trudności w stosowaniu słuszności wskazują również Zbigniew Radwański i Maciej Zieliński, którzy uważaja, że odwołuje się ona do podstawowych i pierwotnych wartości moralnych, niekoniecznie skonkretyzowanych w utrwalonych w społeczeństwie regułach postępowania ${ }^{52}$. Aby uchronić przed dowolnościa powoływania się na słuszność, SN formułuje pewne wskazania w tym zakresie, np. odnośnie do stosowania zasad słuszności wynikających z 102 k.p.c. ${ }^{53}$, jednakże wobec ustaleń poczynionych w ramach niniejszych rozważań można mieć wątpliwości co do ich skuteczności.

Na zakończenie wymaga podkreślenia, że pomimo ograniczonego występowania słuszności w polskich aktach prawnych, praktyka orzecznicza wykracza szeroko poza ramy nakreślone przez ustawodawcę. Wydawać się może, że słuszności znaczenie nadaje dopiero sąd na etapie stosowania prawa, podczas procesu interpretacji i dobierania argumentów na potrzeby orzeczenia. Tak

${ }^{51}$ Mojak (2016): 60.

${ }^{52}$ Radwański, Zieliński (2007): 342.

${ }^{53}$ Postanowienie SN z 17 kwietnia 2013 r., V CZ 132/12: „Cena istnienia przesłanek objętych art. 102 k.p.c. ma charakter dyskrecjonalny, oparty na swobodnym uznaniu sądu, kształtowanym własnym przekonaniem. Nie oznacza to jednak dowolności w decydowaniu o zasadzie orzekania o kosztach i przesłankach zastosowania jednej z nich. Sąd jest zobowiązany do przytoczenia w uzasadnieniu orzeczenia podstaw dokonanej oceny oraz jej wyniku, w sposób umożliwiający odtworzenie przyjętych założeń i wartościowań”. 
daleko posunięta samodzielność sądów w używaniu argumentu ze słuszności może budzić pewne wątpliwości natury aksjologicznej. Uznanie bowiem przez sąd in concreto, że pewne działanie „naruszałoby poczucie słuszności” lub że za pewną decyzją „przemawiają względy słuszności”, jest uzależnione od procesu wartościowania podjętego przez organ orzekający i wyboru akceptowanego rozumienia słuszności. Przedstawione wyniki analizy orzecznictwa wskazują na niepokojące zjawisko w orzecznictwie polskim, które może stanowić zagrożenie dla - zagwarantowanej w art. 32 Konstytucji $\mathrm{RP}^{54}$ - zasady równości wobec prawa, a także w powszechnego poczucia sprawiedliwości. Jak pisze Andrzej Bator: „prawnicza władza dyskrecjonalna nad tekstem staje się dyskretną władzą nad prawodawstwem, a w konsekwencji, także do pewnego stopnia nad społeczeństwem" ${ }_{55}$. Podsumowując, o ile trudno wskazać jednolite znaczenie słuszności in abstracto, o tyle można ją pojać a casu ad casum ${ }^{56}$, zdefiniowana przez wypełnienie jej odpowiednią treścią (najczęściej aksjologiczna) w konkretnej sytuacji faktycznej. Innymi słowy, znaczenie słuszności zależy od decyzji sądów, a bez nich słuszność to tylko „abrakadabra, słowo bez znaczenia $^{57 "}$.

Bator, A. (2014). Polityczne interpretacje analitycznej teorii prawa, [w:] M. Zirk-Sadowski, B. Wojciechowski, T. Bekrycht (red.), Integracja zewnętrzna i wewnętrzna nauk prawnych. Część 1 (Jurysprudencja 2): 11-38.

Bautro, E. (1925). Prawne poczucie jako przejaw i forma podświadomego, skrótowego myślenia. Część pierwsza. Historyczno-pragmatyczna. Warszawa.

Bentham, J. (1962). A rationale of judicial evidence, [w]: J. Bowring (ed.), The Works of Jeremy Bentham. Vol. 7. New York.

Leszczyński, L. (2000). Funkcje klauzul odsyłających a model ich tworzenia w systemie prawa. Państwo i Prawo 75(7): 3-17.

Leszczyński, L. (2011). Kategoria słuszności w wykładni prawa. Studia Iuridica Lublinensia 15: $45-56$.

Leszczyński, L. (2016). Generalne klauzule odsyłające - ujęcie teoretycznoprawne. Annales Universitatis Mariae Curie-Skłodowska. Sectio G. Ius 63(2): 22-26.

Mojak, J. (2016). Dobre obyczaje w polskim prawie kontraktowym - wybrane zagadnienia. Annales Universitatis Mariae Curie-Skłodowska 63(2): 57-70.

Nazaruk, P. (2019). Komentarz do art. 5 kodeksu cywilnego, [w:] J. Ciszewski, P. Nazaruk (red.), Kodeks cywilny. Komentarz. Warszawa.

Nowacki, J. (1988). O przepisach zawierających klauzule generalne, [w:] A. Bodnar, J. Wiatr, J. Wróblewski (red.), Prawo i polityka. Warszawa: 78-101.

Pawełczyk, M. (1984). Uwagi o „odsyłającym” charakterze klauzul generalnych. Studia Iuridica Silesiana 9: 81-99.

Pawełczyk, M. (1982). Klauzula generalna sumienności i staranności pracowniczej, [w]: T. Zieliński (red.), Z problematyki prawa pracy i polityki socjalnej. Tom 5. Katowice: 95-112.

Radwański, Z., Zieliński, M. (2007). Klauzule generalne w prawie prywatnym, [w:] M. Safjan (red.), System prawa prywatnego. Tom 1: Prawo cywilne - część ogólna. Warszawa: 333-342.

${ }_{54}$ Art. 32 Konstytucji Rzeczypospolitej Polskiej z 2 kwietnia 1997 r. (Dz. U. 1997, Nr 78 poz. 483): „1. Wszyscy są wobec prawa równi. Wszyscy mają prawo do równego traktowania przez władze publiczne. 2. Nikt nie może być dyskryminowany w życiu politycznym, społecznym lub gospodarczym z jakiejkolwiek przyczyny".

55 Bator (2014): 15.

56 Wyrok TK z 25 lipca 2013 r., P 56/11.

${ }^{57}$ Bentham (1962): 328. 
Sobański, R. (2001). Słuszność w prawie. Państwo i Prawo 56(8): 3-12.

Tkacz, S. (2003). Rozumienie sprawiedliwości w orzecznictwie Trybunału Konstytucyjnego. Katowice.

Wróblewski, J. (1963). Wartości a decyzja sądowa. Wrocław.

Wróblewski, J. (1970). Słuszność w systemie prawa polskiego. Ruch Prawniczy, Ekonomiczny i Socjologiczny 32(1): 97-116.

Zajadło, J. (2008). Po co prawnikom filozofia prawa? Warszawa.

Zajadło, J. (2017). Sumienie sędziego. Ruch Prawniczy, Ekonomiczny i Socjologiczny 79(4): 31-41.

Ziembiński, Z. (1980). Problemy podstawowe prawoznawstwa. Warszawa.

Ziembiński, Z. (1989). Stan dyskusji nad problematyką klauzul generalnych. Państwo i Prawo 44(3): 14-24.

Zirk-Sadowski, M. (2000). Wprowadzenie do filozofii prawa. Kraków.

\section{THE CATEGORY OF EQUITY IN POLISH JURISPRUDENCE}

\section{Sum mary}

The article provides a philosophical and legal analysis of the category of equity in the jurisprudence of Polish courts. The author distinguishes two main ways of invoking equity by courts: 1) indirect - by applying a provision containing a general clause indicating equity or other values, and 2) direct - by voluntarily invoking equity under the discretionary power of a judge. The author presents examples from Polish jurisprudence showing why courts rely on equity on their own initiative. An appeal to equity may confirm the results of the performed interpretation, or it may oppose them. Courts use the argument of equity also when justifying partial decisions that are crucial for making a final decision, and even with less binding decisions, such as demands for a change in the law. At the end, conclusions are formulated regarding the understanding of equity a casu ad casum and the going beyond the framework outlined by the legislator in this respect. The author concludes that in many cases the court gives meaning to equity only at the stage of applying the law, during the process of interpreting and selecting arguments for the purposes of a judgment. Moreover, it is concluded that courts often refer to equity without explaining this concept or justifying its application. Therefore, one may be tempted to conclude that it is impossible to avoid even a small dose of subjectivism when invoking equity.

Keywords: equity; jurisprudence; application of law; axiology of law 